\title{
Obituary
}

Tutun Mukherjee $\left(17^{\text {th }}\right.$ November $1952-7^{\text {th }}$ January 2019)

\section{SAYANTAN MONDAL}

Tutun Mukherjee was an awe-inspiring name during my M.A. days. She was a joint professor of Comparative Literature and Communication Studies. We looked at her interdisciplinary works with the departments of History, Media Studies, Sociology and thought, like most of M.A. students; it would have been nice if she was our teacher. She did become my teacher as I joined her centre for M.Phil. and got a chance to work with her.

On a beautiful monsoon day in August 2011, I along with 7 other students who joined the Centre for Comparative Literature for M.Phil. went to our first class. We were all excited for this new journey. We were eager for the HoD to come in and probably dispel some of our worries or make us more worried. It was my first classroom interaction with Prof. Tutun Mukherjee.

That class ended with not only dispelled worries and a confidence in our respective proposals but with a sense of relief that no matter which background we came from, we are all good and worthy. All of us struggled with fine tuning our proposals, reading, interpretations, analysis and of course, writing. But we never ever had hesitation or doubt that we could not. Prof. Tutun Mukherjee was such a force in our lives. As I got to know her more in the coming years, I realised it was not a mere coincidence with us. Prof. Mukherjee made it the first lesson for all her classes to instil that confidence among students. And she would follow it up by encouraging peer-learning, sharing recent journal articles relevant to our research and keeping us updated. She invested a lot of energy in building platforms inside and outside the department for 
students to share their work in progress, the annual students' conference- Researchers at Work is one such example. The short-lived department journal e-dhvani was another such platform for senior students to work along with subject experts and know how an academic journal is run. In her latest contribution to digital learning, building of e-resources in epgpathshala she was no different. As I look back at what all she had been doing, today it seems she dedicated her life and teaching to create confident researchers who are not afraid to push boundaries and venture out of their comfort zones. She set a wonderful precedence in encouraging her students to go for conferences, apply for fellowships and never stopped following it up. In case of rejection, she would always be ready with a new opportunity and that's how she never let a student dwell on rejections but kept opening new windows for them.

Prof. Mukherjee will be remembered, by generations to come, for her contributions in the field of Comparative Literature, Translation Studies, Performance Studies, Gender Studies to name a few. Her academic journey which started from the city of Patna found its first expression in the work The Chicago Critics: An Evaluation (1991) and flourished through decades of work in the fields of Comparative literature. It was no coincidence that she was the prime architect of Centre for Comparative Literature in the University of Hyderabad and went on to organise numerous lecture series, conference, literary meet to promote exchanges among literary cultures. Her academic rigor was focussed on core areas of Comparative Literature. While she was proposing Translation: From Periphery to Center Stage (1998) as a thesis, she simultaneously kept working in translations of plays, poems and novellas. Acts of Resistance (2005), Five Novellas by Women (2008) were some of the outcomes. Similarly, performance, particularly theatre, was another area of her interest which found its reflection in her works like - Girish 
Karnad's Plays: Performance and Critical Perspectives (2006), The Plays of Mahesh Dattani (2012) and Androgyny and Female Impersonation in India (2016). Prof. Mukherjee loved her discipline and had a keen awareness of its changing contours. Her edited work, Humanities in the Present Context (2009), Companion to Comparative Literature (2013) and creation of numerous popular modules in the digital platform of epg Pathshala are perfect examples of that awareness and love.

Prof. Tutun Mukherjee will be remembered for the love of the subject that made her work so special and her works on theatre, her translations will keep bearing the testimony of that love. But for us, her students, she will always have a special place in our memory because of her tireless contribution in making us what we are today - a researcher, a teacher. And we will keep remembering her as a teacher with a bright smile, with all the time in the world to listen to her students and take away all worries, nervousness and embarrassments. 